\title{
THE DEVELOPMENT OF A WEST COAST DAIRY FARM IN A HIGH RAINFALL AREA
}

\author{
A. H. WOODHAM \\ Farmer, Kowhitirangi
}

\section{Abstract}

The development and management of a West Coast dairy farm at Kowhitirangi is described. Problems peculiar to intensive dairying in a high rainfall area are outlined.

\section{HISTORY OF THE KOWHITIRANGI DISTRICT}

THE Kowhitirangi district in which we farm is approximately $16 \mathrm{~km}$ south-east of Hokitika, bounded by the Southern Alps in the east, and two major rivers, the Kokatahi in the north-east and the Hokitika on the south-west side.

Land was first settled over 100 years ago and used mainly for cattle grazing. The few cows milked were for the farm's own needs including feeding a few pigs, any surplus being made into homemade butter and sold.

Around 1901, the late James Smith donated a small area of land in the centre of the district for a creamery. All milk was sent there to be separated and the cream taken across the river to be made into butter at the Kokatahi butter factory.

With the closure of this creamery in 1918-9, farmers had to separate their own cream and deliver it to collection points to be picked up. In 1937, the Kokatahi factory was closed, and all cream sent to Hokitika for processing.

Now the Westland Co-op. Dairy Company factory at Hokitika is supplied with whole milk from 45 dairy farms in the area. Total milkfat production for the area in 1977-8 was $843405 \mathrm{~kg}$ for an average of $18742 \mathrm{~kg} /$ farm.

\section{FARM DESCRIPTION AND DEVELOPMENT}

The farm is. $25 \mathrm{~km}$ south-east of Hokitika on the eastern side of the Kowhitirangi Valley, backing on to the Kokatahi River. 
Total area is 128 ha, comprsing 80 ha of Hokitika silt loam (up to $100 \mathrm{~cm}$ thick overlying schist gravel) with medium natural fertility and good drainage, and 47 ha of Karangarua silt and peaty loam of medium to low natural fertility and poorly drained. Altitude is $60 \mathrm{~m}$ above sea level, annual rainfall averages 3850 $\mathrm{mm}$, and the property is open to winds from all quarters. Two major creeks and minor waterways running through the property are seldom dry. Despite the high rainfall, the climate is generally mild with vigorous grass growth in the spring and autumn and limited growth through the winter.

\section{DEVELOPMENT}

The development of this farm has had a chequered course over the past 28 years. We first became part-time farmers in 1952 with the purchase of 45 ha of Karangarua silt and peaty loam, formerly Hokitika Borough leasehold ground with 21 years right of renewal, for $\$ 95.60 /$ ha. Fencing was poor, and the area was carrying only 22 steers. The only building was a small house. In the first year, while I was working at the local sawmill, we built a 3-cow doubleup internal race cowshed and purchased a milking plant at a clearing sale for $\$ 70$.

The steers were sold and the 30 cows and heifers purchased for the 1952-3 milking season produced $2260 \mathrm{~kg}$ butterfat.

Development of better pastures commenced with drainage in 1953. A $1100 \mathrm{~m}$ main drain was cut by dragline through the middle of the property at a cost of approximately $\$ 61$ per $100 \mathrm{~m}$. A little later 900 tonnes of metal was spread for a main race at a cost of a little over $\$ 40$ per $100 \mathrm{~m}$. No furthes development was made over the next 2 or 3 years until a loan from Marginal Lands Board helped finance a new Fordson tractor, mower, plough and disc, which enabled us to speed up development by mowing, discing and oversowing with seed, superphosphate and lime.

By 1957 cow numbers had increased to 40 and, with a target of 4000 to $4500 \mathrm{~kg}$ milkfat in sight, we added another 6 ha of good Crown leasehold land which backed on to our property. With tractor and plough this was bought into production for the 1958 milking season, and, with the purchase of 15 more cows, $5400 \mathrm{~kg}$ milkfat was the target. By this time the house was too small for our family of two adults and three children but with the help of a \$4000 loan from the Marginal Lands Board a new house was built during 1958. As we had not reached our production target, 
the Board would only give their approval provided we worked to a tight budget under their supervision.

\section{The 1958 Season}

Unfortunately, this season developed into a crisis season when nature turned against us. As the season was very wet, little winter feed was conserved and hay had to be bought in from outside the West Coast. In January, the Kokatahi River left its course, washed away all our new grass and fencing from the 6 ha, and covered quite a few adjoining paddocks with water, silt and driftwood. Clearly some quick decisions had to be made.

The first was to call in the catchment Board and assess the possibilities of putting the Kokatahi River back into its original course. This proved impossible at the time as a major scheme was required involving a number of other farmers on the top side of our property.

Secondly, what were the prospects for the 1958-9 season? With the loss of productive area, cow numbers had to be reduced to 35 , which would mean insufficient returns in butterfat to meet our commitments. After discussions with our bank manager, and again with the Marginal Lands Committee, we were put on a month-to-month budget with our case being reviewed every three months.

It was evident and agreed that more land was needed. The question was where and how, as any available farmland was quickly taken up by more established farmers with better finance. So, for the next 4 or 5 years my wife milked our 35-38 cows while I went out contract fencing and cultivating for local farmers.

\section{RIVER Protection}

About 1964, the Crown purchased a block of ground now known as Lake Arthur Farm Settlement east of our property with a long river frontage backing on to the Kokatahi River. As a result, in 1965 the Westland Catchment Board were able to draw up an overall river protection scheme incorporating the Lake Arthur Block and five local farmers along the river except the one that was on the bottom side of our property. As this farmer would not take part in the scheme, the project ended half-way across our frontage, giving only partial protectian from any further flooding.

By February 1966 the Soil Conservation and Rivers Control Council had approved the scheme and our contribution to. the 
overall scheme of $\$ 1600$ was met out of income. This scheme enabled us to increase our holding to its original size at a cost of $\$ 128 /$ ha for river protection. The new area, although in a rough state and of low natural fertility, brought our total acreage up to 57 ha at a cost of $\$ 173 /$ ha. Cow numbers were still 38 but production had increased to $4200 \mathrm{~kg}$ milkfat in 1966 with an average of $110 \mathrm{~kg} / \mathrm{cow}$.

\section{FARM Expansion}

Shortly after this the farm on the top side of our property was on the market. The 64 ha property had soil types similar to our own farm, but was in a rundown state. With another loan from the Marginal Lands Board this property and buildings were bought for $\$ 13000$ ( $\$ 100 / \mathrm{ha})$, plus an additional 40 dairy cows. Our first season as full-time dairy farmers again saw an increase from $4200 \mathrm{~kg}$ milkfat in 19656 from 38 cows, to $9400 \mathrm{~kg}$ milkfat from 80 cows inthe 1966-7 season, an average of $118 \mathrm{~kg} / \mathrm{cow}$.

\section{Development of Purchased Area}

Over the next three years our development programme was to be met out of income. The first priority was a central race to provide better access to all paddocks on the new property, and linking this with our existing farm race system. This was completed at a cost of $\$ 60 / 100 \mathrm{~m}$. Drainage was bad, and a spin drainer on the tractor was used extensively with good results, although a dragline had to be used to clean out existing waterways.

Fertilizer was applied at the rate of 1 tonne superphosphate for every $1000 \mathrm{lb}$ milkfat which was 20 tonnes the first year and increased each year thereafter as milkfat increased. On the wetter soils lime was needed at a rate of 5 to 6 tonnes/ha to bring the $\mathrm{pH}$ up to an acceptable level. Copper was injected into the young stock and any cows that showed signs of copper deficiency.

\section{Grazing Management}

The electric' fence was used as much as possible to ensure the 125 cows received a new break of grass (approximately 1.2 ha) after each milking. Later this was replaced by permanent electric fencing. This proved very effective on the wetter land in later years with very little pugging from 125 cows on very wet days. By 1969 production had reached $13470 \mathrm{~kg}$ or $107 \mathrm{~kg}$ milkfat/ cow. 
NEW FARM PURCHASE

By now our 3-cow double-up milking shed was proving inadequate and something had to be done to increase its size or build a new one. Fortunately, our problem was solved when we had an offer to take part in an amalgamation with two other farmers in the purchase of our neighbour's farm which had a good 4-cow double-up milking shed on it, plus other good outbuildings. We sold our original farm of $57 \mathrm{ha}$, and brought 63 ha of good land with the buildings on it for a change-over price of $\$ 2000$, bringing the farm to its present size.

The new area had a ragwort and cutty grass problem. Ragwort has been controlled with $2,4-\mathrm{D}$, but as yet we still have the cutty grass which will be treated with "Roundup" herbicide. Our farm management has remained similar to that of the previous farm. By 1975 milking was taking 51/2 hours a day, leaving little time for other farm work. We decided to install a 17-cow "N.D.A. Turn Style" circular milking platform at a total cost of $\$ 17500$, most of the work being carried out with help from local farmers. Milking time was reduced to $2 \frac{1}{2}$ hours per day.

Milkfat production increased over the following three years from $16748 \mathrm{~kg}(127 \mathrm{~kg} / \mathrm{cow})$ in $1975-6$ to $20737 \mathrm{~kg}(144 \mathrm{~kg} /$ cow) in 1977-8.

In the very wet $1979-80$ year production was down to $133 \mathrm{~kg}$ / cow (18 $548 \mathrm{~kg}$ ), but this will pick up when the ground dries out. Following our usual fertilizer practice outlined earlier, fertilizer usage has increased with production.

\section{SEASONAL MANAGEMENT PROGRAMME}

APRIL-JULY

Depending on the season, all cows are dried off by the middle of May. Rotation is lengthened to 90 days or longer at a stocking rate of 32 cows to the hectare on all-grass, using hay as a supplement when required. This feed pattern is continued until calving. In a wet season we would dry off our thin cows by the end of April, and the rest of the herd as climatic conditions dictate, trying not to damage the pasture too much before going into winter.

All grassed areas to be used for milking receive an application of $500 \mathrm{~kg} / \mathrm{ha} 30 \%$ potassic superphosphate. Calving commences on 5 September, cows and heifers calving together. The early calvers graze the pasture used at the beginning of the winter grazing rotation, with some hay used as necessary. 


\section{OCTOBER-NOVEMBER}

The milking cows are fed as much grass as is available, no areas beng closed for conservation until late November.

\section{DECEMBER- JANUARY}

Enough paddocks are closed to ensure at least 3000 bales of hay are made in January, using our own machinery apart from contract baling.

\section{FEBRUARY - MARCH}

At this time we are saving grass for the autumn and early winter months by extending the grazing rotation as much as possible without reducing milk production too much.

\section{SUMMARY}

What have we achieved after 28 years of part- and full-time dairying?

It has been a big challenge to me and my family to meet and overcome our problems and to see our milk production increase from a meagre $2270 \mathrm{~kg}$ in 1952 to $20740 \mathrm{~kg}$ in 1978 .

There is still room for improvement, and a great future left in this farm for a younger man who is prepared to apply present-day farming methods and use his own skills. A recent survey of the property showed that its potential could be as high as 1700 stock units or 200 cows and 50 replacements.

Our district is developing rapidly and holds a good future for those who want to join in and be part of it.

\section{ACKNOWLEDGEMENTS}

We have had the help of many people over the years, especially the farmers in the district in the early 1950s, the Bank of New Zealand, Dairy Board and MAF advisers, the Westland Co-op. Dairy company and our accountant, Wilf Smith. Acknowledgements are also due to Eric Smith who helped with the district's early history, and most of all my family, especially my wife, for being a wonderful consultant over all these years. 